\title{
Morphological characterization and productivity estimates of Acrocomia totai Mart. (Arecaceae) - a sustainable alternative of extractivism and cultivation
}

\author{
Suelen Alves Vianna ${ }^{1}$, Helen Liepkan Maranhão Domenech ${ }^{2}$, Rosa Helena da Silva ${ }^{3}$, \\ Carlos Augusto Colombo ${ }^{4}$, Arnildo Pott ${ }^{4}$ \\ Abstract -The Acrocomia totai palm can be found in areas of Cerrado and Pantanal in Brazil, \\ Argentina, Bolivia and Paraguay. Its fruits are used by traditional and rural communities \\ for subsistence or income source. Given the relevance of this genetic resource, we assessed \\ the morphological and agronomic characters and estimated the population density in two \\ physiognomies of the Pantanal. We found variation in all analyzed characters, such as the density \\ of spines on the stipe, coloration of leaves, epicarp and mesocarp. The average number of fruits \\ per bunch was $392.30 \pm 134.53$, fresh mass ( $\mathrm{g}$ ) of the whole fruit of $15.50 \pm 3.87$ and, the mesocarp \\ oil content (\%) of $14.94 \pm 8.06$. The population density varied between $48 \mathrm{pls}^{-h^{-1}}$ in area of \\ shrubby grassland to $287 \mathrm{pls} \mathrm{ha}^{-1}$ in open grassland. We estimated yields per hectare of $8.65 \mathrm{t}$ of \\ fruits, $4.77 \mathrm{t}$ of pulp and $270 \mathrm{~kg}$ of oil in areas of shrubby grassland and $1.45 \mathrm{t}$ of fruits, $0.8 \mathrm{t}$ of \\ pulp and $50 \mathrm{~kg}$ of oil in areas of open grassland. The data demonstrate the potential of profitable \\ exploitation of the species in extractive or cultivation. The variation found can be useful for the \\ genus taxonomy, breeding and conservation programs. \\ Index terms: native fruit, palm tree, plant breeding, Pantanal.

\section{Caracterização morfológica e estimativas de produtividade de Acrocomia totai Mart. (Arecaceae) - uma alternativa de extrativismo e cultivo sustentáveis}

\begin{abstract}
Corresponding author: suelen.loesch@gmail.com

Received: October 20, 2020 Accepted: January 04, 2021

Copyright: All the contents of this journal, except where otherwise noted, is licensed under a Creative Commons Attribution License.
\end{abstract}

\begin{abstract}
Resumo - A palmeira Acrocomia totai pode ser encontrada em áreas do Cerrado e do Pantanal, no Brasil, Argentina, Bolívia e Paraguai. Seus frutos são utilizados por comunidades tradicionais e rurais como meio de subsistência ou como fonte de renda. Da importância deste recurso genético, foram realizadas a avaliação de caracteres morfológicos e agronômicos, e a estimativa da densidade populacional em duas fisionomias do Pantanal. Foi encontrada variação em todos os caracteres analisados, tais como: a densidade de espinhos no estipe, a coloração das folhas, do epicarpo e do mesocarpo. O número médio de frutos por cacho foi de $392.30 \pm 134.53$, massa fresca $(\mathrm{g})$ de um fruto inteiro de $15.50 \pm 3.87$ e teor de óleo (\%) no mesocarpo de $14.94 \pm 8.06$. A densidade populacional variou de 48 pls.ha $^{-1} \mathrm{em}$ área de 'campo sujo' a $287 \mathrm{pls}$ ha $^{-1} \mathrm{em}^{2}$ áreas de 'campo limpo'. Estima-se a produção por hectare de $8.65 \mathrm{t}$ de frutos, $4.77 \mathrm{t}$ de polpa e $270 \mathrm{~kg}$ de óleo, em áreas de 'campo sujo', e $1.45 \mathrm{t}$ de frutos, $0.8 \mathrm{t}$ de polpa e $50 \mathrm{~kg}$ de óleo, em áreas de 'campo limpo'. Os dados demonstram a possibilidade de exploração rentável da espécie via extrativismo ou cultivo. A variação encontrada pode ser útil à taxonomia do gênero, a programas de melhoramento e à conservação.

Termos para indexação: fruto nativo, palmeira, melhoramento vegetal, Pantanal.
\end{abstract}




\section{Introduction}

Because of the increasing demand for food and energy resources, agriculture underwent a high specialization with reduced genetic variability of cultivated species, though very productive, present fragility facing environmental adversities and plant health problems. Consequently, most modern large-scale production of raw matters of plant resources do access a restricted number of species in view of the enormous existing biodiversity. Taking as an example the species utilized for human food, half of the ingestion of protein and calories comes from only three plant species, corn, rice and wheat (WARREN 2015), while those already described add to nearly 369,000 species, besides many yet unknown or little studied that can have potential economic use as food, medicinal, biofuels and others (WILLIS 2017). Thus, the need for diversifying the use of plant species becomes evident, which leads to the prospection of wild species and or those used by traditional communities in extractivism or some degree of cultivation. However, as the primordial factor for the utilization of new genetic resources is their characterization under several aspects, the most relevant and primary being morphology and productivity.

Although Acrocomia palms have been exploited as fruit plants for a long time by indigenous people and traditional or rural communities (PATIÑO-RODRIGUEZ 2002; MORCOTE-RÍOS; BERNAL 2001; OLIVEIRA 1996; LENTZ 1990), their recognition as oil crops is the most recent, leading to an exponential growth of research in various areas of knowledge and cultivation at commercial scale. Among the nine species accepted of the genus (VIANNA; CAMPOS-ROCHA 2020; TROPICOS, 2021; THE PLANT LIST 2013), A. aculeata (Jacq.) Lodd. ex Mart. (Arecaceae) is the most studied and already commercially exploited for presenting broader geographic distribution, bigger and heavier fruits and higher of pulp oil content (COLOMBO et al. 2018). However, it shall be considered that other species of the genus are resources already long utilized by local people, not only for oil extraction as well as other purposes. Furthermore, from the environmental point of view, for presenting a more restricted geographic distribution, measures should be taken for conservation of their native populations.

Among the species of the genus, Acrocomia totai Mart. occurs in parts of Bolivia, Paraguay, Argentina and in Brazil, in the western portion of the state of Mato Grosso do Sul and northwest of Paraná (VIANNA; CAMPOSROCHA 2020, TROPICOS, 2021), in the Pantanal and Cerrado, that is the Brazilian savanna (LORENZI et al. 2010). It is used by rural and traditional communities and presents an excellent potential for commercial exploitation. The species has diversified use, the stipe is applied in buildings (rafts and lats), besides containing starch (POTT; POTT 1994). The leaves are used to cover rooves, obtain fibers for lines, ropes and hammocks, high-quality forage for horses and dairy cows, and the sweetish heart of palm can be consumed fresh or cooked (DAMASCENO-JR; SOUZA 2010; MORAES 2004; POTT 1986). The roots in some places are used in folk medicine as a diuretic and against abscesses and respiratory diseases. The fruit pulp, nutritionally rich (AMARAL et al. 2019; MUNHOZ et al. $2018^{\text {ab; }}$;IANNA et al. 2015; RAMOS et al. 2008), is consumed fresh or to prepare ice creams and juices, or flour for several local food products such as cakes and biscuits, jams, candies or as a food industry ingredient (SILVA et al. 2020; AGUILERA et al. 2018; MARCONDES et al. 2018; SILVA et al. 2018). The endocarp can be used as crushed rock or as activated charcoal (FLORES-JOHNSON et al. 2018). The nut is consumed fresh or toasted, ground for sweets, and its excellent quality oil is edible or for cosmetics (MUNHOZ et al. 2018; POTT; POTT 1994). Even the spines of stipe can have a pharmacological application, as they have compounds with biological activity as antibacterial, antiviral and against some types of cancer and some protozoa (SOUZA et al. 2017).

The morphological characterization provides biometric data useful to calculate yield and estimate the productivity of different plant parts, basic information for planning sustainable extractivism, implantation of commercial plantings, industrial applications, genetic improvement and conservation plans, as well as to subsidize taxonomic, ecological and other studies. Aware of few available studies on the morphological characterization of $A$. totai and the lack of information on its yield and productivity, we performed such analyses in natural populations of the species, providing essential information to the market, sustainable extractivism, cultivation and research. 


\section{Material and methods}

\section{Location and characterization of the study area}

We sampled three natural populations of $A$. totai located in the municipality of Corumbá, Mato Grosso do Sul, Brazil, in the western border of the Pantanal, in the rural communities of Antônio Maria Coelho, São Gabriel, and São Domingos (Figure 1), circa 20 to 30 $\mathrm{km}$ afar from each other. Soils are predominantly clayey and calcareous, fertile but shallow (CARDOSO et al., 2002). The climate by the Köppen-Geiger classification is type Aw, with a mean annual temperature of 25.4 ${ }^{\circ} \mathrm{C}$ and mean annual rainfall of $1074 \mathrm{~mm}$ (CLIMATE-
DATA.ORG 2020). According to Pott and Pott (1994), the species frequently occurs in flood-free or running flood areas of the Pantanal, on sandy or clayey soils and limestone hills, and rarely in the east zone of the Pantanal, with calcium-poor soils. We considered them three populations since probably there is no gene flow between them because of distance. It is known that the plants of the species present a mixed reproduction system, being preferentially allogamous when in areas with higher population densities and can be autogamous in areas with few plants (CARGNIN et al., 2008). Additionally, we know (ongoing study by the team) that the pollinators do not travel long distances.
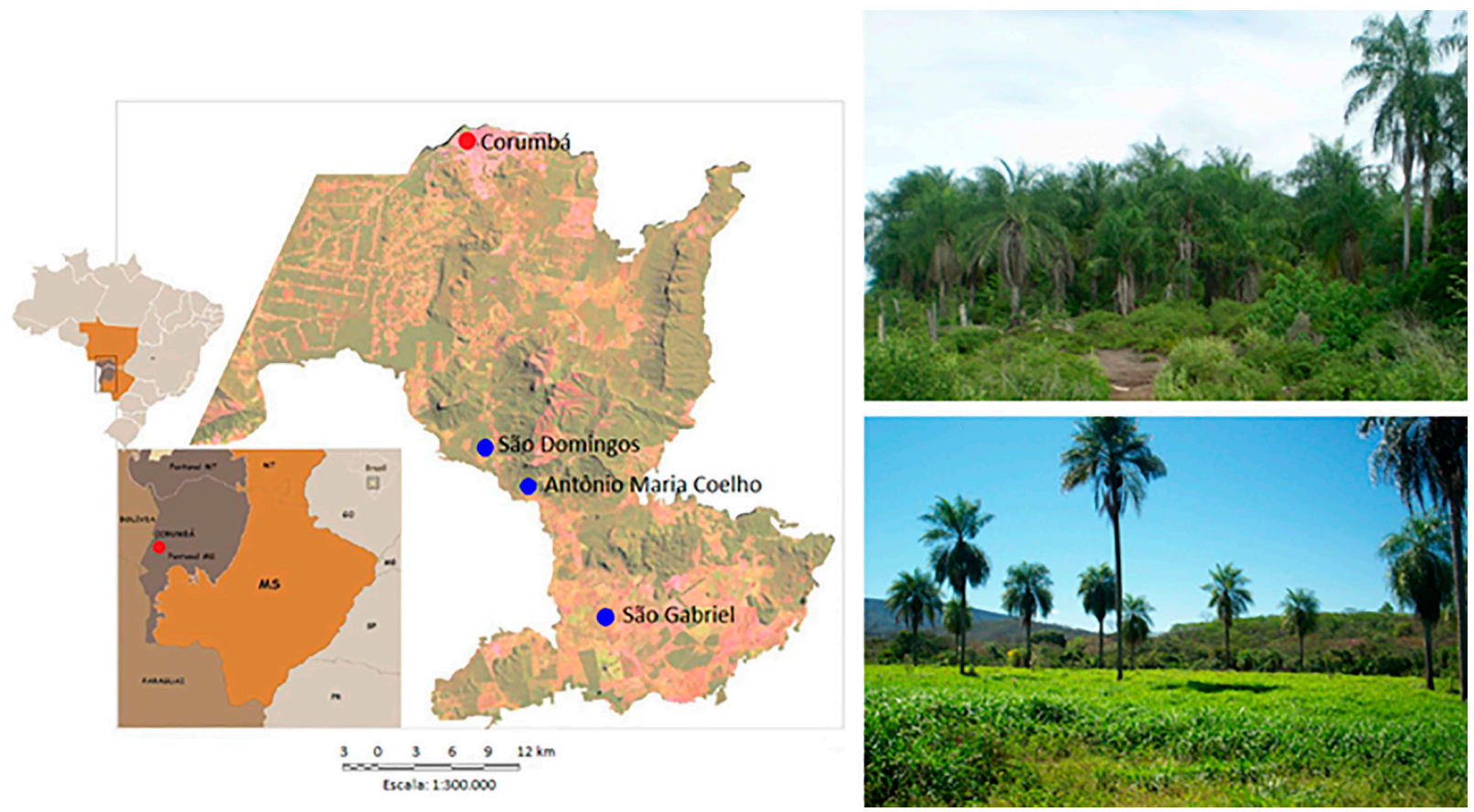

Figure 1. Selected sites for the study. Natural populations of Acrocomia totai located in the rural communities: a Antônio Maria Coelho, b São Domingos.

Selection of individuals and evaluated morphological characters

We evaluated 49 morphological characters on 66 individuals distributed within three populations of contrasting plants to represent the highest possible variability concerning the variation of size, shape, and coloration of fruit peel and pulp.

To assess the vegetative parts, we observed or measured 25 quantitative and qualitative characters on different parts of the plant: stipe (i) basal circumference (just above the soil), (ii) circumference at breast height, presence or absence of the remaining leaf base (sheath) in the (iii) basal, (iv) middle (v) or apical portion, presence of spines in the (vi) basal, (vii) median (viii) or apical portion, their density being estimated by visual criterium in absent, few, medium or much presence of spines; leaf (i) total length measured from the first pinna inserted on the rachis basis to the apex, (ii) number of pinnas on the right side, (iii) color das pinnas by direct observation, (iv) pinna insertion angle on the rachis, length of 4 pinnas in the (v) basal, (vi) middle and (vii) apical portion, presence or absence of trichomes on the adaxial leaf rachis in the (viii) basal, (ix) middle and (x) apical portions, presence or absence of trichomes on the abaxial side of the leaf rachis in the (xi) basal, (xii) middle and (xiii) apical portions, density of occurrence (very high, high, medium, low, inexistent) of spines arranged laterally on the leaf rachis on the (xiv) face adaxial and (xv) abaxial face, and spine mean length on the leaf rachis on the (xvi) abaxial and (xvii) adaxial face. 
Regard the reproductive part, we analyzed 24 characters: inflorescence (i) color; infructescence (i) length, (ii) circumference in the median region, (iii) rachillae, (iv) number of female flower scars, (v) number of fruits, (vi) fresh weight (rachis + rachillae + fruits); fruits (i) color of the epicarp and (ii) color of mesocarp determined by visual criterium determined by the same person for standard observations, (iii) presence or absence of trichomes on the epicarp, (iv) presence or absence of stripes on the epicarp, (v) presence or absence of calyx, (vi) longitudinal diameter (length) and (vii) equatorial diameter (diameter) of the fruit, fresh weight of the (viii) whole fruit, (ix) epicarp, (x) mesocarp, (xi) pyrene (endocarp + endosperm); dry weight of (xii) whole fruit, (xiii) epicarp (peel), (xiv) mesocarp (pulp), (xv) pyrene (endocarp + endosperm), (xvi); oil content of the mesocarp (pulp \%) de 40 individuals, and (xvii) ratio length-width ratio (LWR) for determination of fruit shape.

We collected two bunches per plant, selected visually between those more mature. For evaluation of fruit characters, we selected 50 fruits per bunch, i. e., 100 fruits per plant. For dry matter determination, we separated 20 fruits into paper bags, dried them in an oven with air circulation at $55^{\circ} \mathrm{C}$ until constant weight. For mesocarp (pulp) oil content, the samples were prepared following methods described by the analytical rules of the Instituto Adolfo Lutz (BRASIL 2005), determining the total fats by direct extraction with organic solvent in a Soxhlet extractor.

\section{Estimates of production in native and cultivated} areas

Aware of the existence of big natural thickets of the species, its economic potential and its utilization by local populations in extractive form, we estimated the populational density in different physiognomies where its occurrence is most frequent, named (i) open grassland - areas predominantly formed by herbaceous vegetation and scattered shrubs, and areas of (ii) shrubby grassland - formed by shrubby-herbaceous vegetation. We placed 04 plots of $50 \times 30 \mathrm{~m}$ in three areas of shrubby grassland and three areas of open grassland, adding to a total of 12 plots per physiognomy. Within each plot, we counted all adult individuals. We assumed a population density of 500 plants.ha ${ }^{-1}$ for a cultivated stand.

From the morphological data and the calculated results of populational density, we estimated the productivity of characters of agronomic interest, such as number of fruits per bunch, fresh and dry mass of the fruit, epicarp (peel), mesocarp (pulp), endocarp (kernel), endosperm (nut) and pulp oil content for each evaluated physiognomy and an assumed cultivated population (500 plants.ha ${ }^{-1}$ ). We considered five bunches per plant for the estimates. We calculated the productivity by extrapolation of the mean populational density of plots of each physiognomy to 1 hectare.
We clarify that the work of 'estimates of population density' and consequent 'estimates of productivity in each one of the physiognomies' was carried out in other areas, not in the same areas where the individuals were analyzed for collection of morphoagronomic data. We took the mean yield of the analyzed individuals in the three populations, and we estimated the productivities of the different physiognomies. Additionally, we point out that the localities where we collected the morphoagronomic data are quite extensive, occurring within each of the different physiognomies. Therefore, we pursued to collect the data in sites with similar physiognomy within each of the localities indicated in the map of Figure 1. To estimate the population densities, we utilized other areas aiming to contemplate the distinct physiognomies.

\section{Data analyses}

The qualitative data were analyzed using the frequency percentage given by multiplying the relative frequency $\left(\mathrm{RF}=\mathrm{AF} / \sum \mathrm{n}\right)$ by 100 . The measured characters, $\mathrm{i}$. e., the quantitative data as well as the results of productivity estimates were statistically analyzed calculating measures of position (mean, standard error, minimum and maximum values) dispersal (coefficient of variation).

\section{Results and discussion}

The analyzed individuals exhibited variation in all evaluated morphological and agronomic characters in a higher or lower degree and, consequently, variation in the productive potential.

\section{Morphological characterization}

The mean values of the circumference at the base and breast height of the stipe $(82.00 \pm 0.34,71.00 \pm 0.32$, respectively) are similar (Table 1), which indicates that the stipe in the analyzed individuals is straight. Stipe diameter variation, according to Dransfield et al. (2008), is common either within or between closely related genera of Arecaceae. In some species, such as the congeneric Acrocomia aculeata, the variation of stipe diameter is ordinarily high; therefore, it is not a useful taxonomic character. 
Table 1. Morphological characterization of the Acrocomia totai palm in native populations of the western zone of the Pantanal in Mato Grosso do Sul.

\begin{tabular}{llcccc}
\hline & Character & Minimum & Maximum & Mean \pm SD & CV\% \\
\hline Stipe & Basal circumference $(\mathrm{cm})$ & 21.00 & 145.00 & $82.00 \pm 0.34$ & 41.42 \\
& Circumference at breast height $(\mathrm{cm})$ & 23.00 & 148.00 & $71.00 \pm 0.32$ & 44.71 \\
\hline Leaf & Length (m) & 1.52 & 3.68 & $2.64 \pm 0.38$ & 14.28 \\
& Number of pinnas per side & 175 & 322 & $236.89 \pm 31.92$ & 13.47 \\
& Length of pinna basal portion (cm) & 43.20 & 92.80 & $66.28 \pm 12.94$ & 19.53 \\
& Length of pinna medium portion (cm) & 45.80 & 101.40 & $74.28 \pm 11.89$ & 16.01 \\
& Length of pinna apical portion (cm) & 23.00 & 68.00 & $45.47 \pm 10.89$ & 23.96 \\
& Length of spines on the leaf rachis - adaxial part & 0.00 & 8.81 & $3.35 \pm 1.45$ & 43.22 \\
& Length of spines on the leaf rachis - abaxial part & 0.00 & 5.70 & $2.33 \pm 1.78$ & 75.92 \\
\hline Infructescence & Length (cm) & 41.50 & 97.00 & $71.07 \pm 9.87$ & 13.88 \\
\cline { 2 - 2 } (bunch) & Diameter (cm) & 34.00 & 108.5 & $82.07 \pm 11.99$ & 14.61 \\
& Number of fruits per bunch & 138 & 805 & $392.30 \pm 134.53$ & 34.29 \\
& Number of rachilla per bunch & 79 & 312 & $135.96 \pm 33.80$ & 24.86 \\
& Number of female flower scars per rachilla & 305 & 2602 & $1040 \pm 403.77$ & 38.79 \\
\hline Fruit & Diameter (cm) & 1.94 & 3.30 & $2.75 \pm 0.28$ & 10.09 \\
& Length (cm) & 2.03 & 3.65 & $2.87 \pm 0.33$ & 11.39 \\
& Ratio length/width (DL/DT) & 0.92 & 1.28 & $1.04 \pm 0.07$ & 6.30 \\
\hline
\end{tabular}

Most studied plants $(75.56 \%, 86.67 \%$ and $88.89 \%$, respectively) did not present remains of the leaf base attached to the stipe in any of its parts - base, middle and apex (Fig 2 a, 3 a). Regard to the presence of spines, most plants were unarmed on the stipe basal $(46.67 \%)$ and middle (35.56\%) portions (Figure $2 \mathrm{~b}$ ). In counterpart, most analyzed plants $(80.00 \%)$ were spiny on the stipe apical portion, with a medium to high spine density. Smooth stipe, without leaf sheath remains, and none or few spines are relevant characteristics for recognition of the species in the field and its distinction from other Acrocomia species (VIANNA; CAMPOS-ROCHA 2020; LORENZI et al. 2010). The presence of spines in the species is highly frequent in young plants and on the stipe apex of adult plants, probably with a function of protection against herbivory; when young to assure full development and when adults, to protect the stipe apical meristem (heart of palm). It should be reminded that most palms have a single meristem, consequently, just one growing point, thus its protection is primordial for survival. That growing point is underground before the stipe elongates.

Among the evaluated individuals, nearly half (42.22\%) presented yellowish-green leaves, followed by $31.11 \%$ green color, and we also observed dark green leaves (11.11\%) and shiny green (15.56\%) (Fig. 2 g) with pinnas inserted in the leaf rachis at the same plane in $75.56 \%$ of plants and $24.44 \%$ in different planes (Figure 2 e). The mean leaf length (m) was $2.64 \pm 0.38$, with a mean number of pinnas on the right side $236.89 \pm 31.92$ and pinna length $(\mathrm{cm})$ on the medium and apical leaf portions of $66.28 \pm 12.94,74.28 \pm 11.89$ and $45.47 \pm 10.89$, respectively (Table 1). Palms of the genus Acrocomia present leaves divided into segments (pinnas) arranged regular or irregularly along the rachis, with a varied total length of leaves and pinnas and various green tones green, the variation being higher between than within each species of the genus (LORENZI et al. 2010). In the analyzed plants, the leaves presented a lower mean total length compared with $A$. aculeata, with higher variation in tones of green and higher occurrence of green-yellowish leaves. The pinnas are irregularly distributed on the rachis and in most plants arranged at the same plane, different from $A$. aculeata, for example, that presents the pinnas inserted in various planes on the rachis. In contrast to $A$. aculeata, with many spines all over the leaf rachis and even on the pinnas, sometimes dense, $A$. totai typically has spines located laterally on the rachis, in lower number and rarely on the pinnas. 
Most leaves lacked spines on the leaf rachis on the adaxial (44.44\%) and abaxial sides (42.22\%) (Figure $2 \mathrm{f}$ ). When present, spines had a mean length of $3.35 \pm 1.45 \mathrm{~cm}$ on the adaxial and $2.33 \pm 1.78$ on the abaxial side (Table 1). However, we observed that most evaluated plants $(42.22 \%)$ had spines on the leaf rachis lateral, where the pinnas are inserted (Figure $2 \mathrm{f}$ ). Dividing the leaf rachis into three parts, base, middle and apex, we noted that most plant parts, $88.89 \%, 97.78 \%, 100.00 \%$, respectively, lacked trichomes (hairs) and, in the few individuals where they occur, they were more concentrated on the basal portion of the rachis (Table 1, Figure $2 \mathrm{c}, \mathrm{d}$ ).
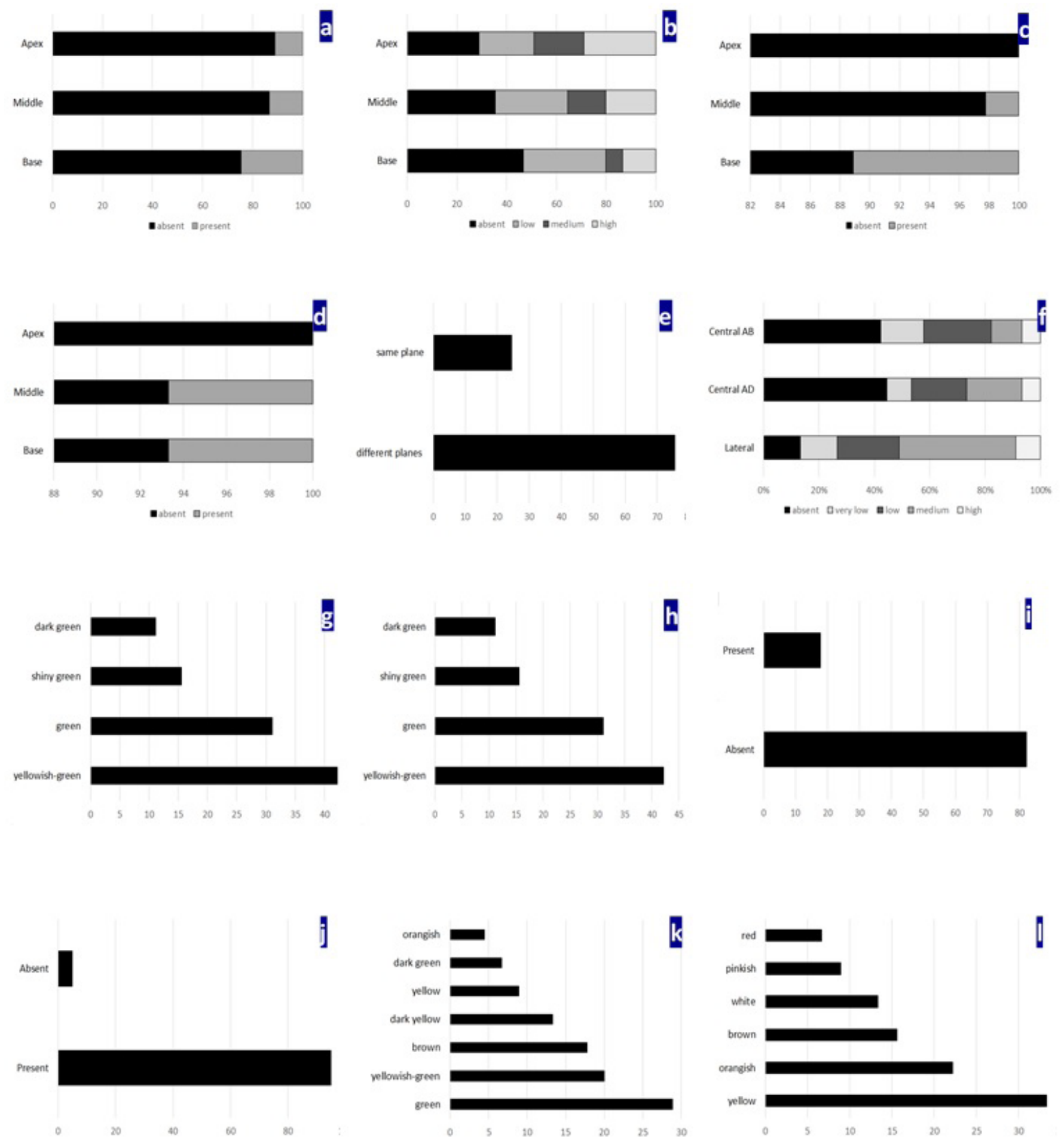

Figure 2. Frequency distribution (\%) of the analyzed qualitative data in palms of native populations of Acrocomia totai in the western zone of the Pantanal in Mato Grosso do Sul: a leaf sheath remains on the stipe b spine density on the stipe, c pilosity on the adaxial side of the leaf rachis, $\mathbf{d}$ pilosity on the abaxial side of the leaf rachis, e type of insertion of pinnas on the leaf rachis $\mathbf{f}$ density of spines on the leaf rachis, $\mathbf{g}$ leaf color, $\mathbf{h}$ stripes on the epicarp, $\mathbf{i}$ trichomes on the epicarp, $\mathbf{j}$ persistent calyx, $\mathbf{k}$ epicarp colors, $\mathbf{l}$ mesocarp colors. 
Probably the spines on the leaves of A. totai, likewise the stipe, exert a function of protection against herbivory. The set of spines present on the apical portion of the stipe can act against attack by large animals as well as insects. Kariyat et al. (2017), studying the function exerted by spines in Solanum spp. verified that they act as an effective defense against caterpillars for restricting their movement on the plant and in some cases keeping them off. Göldel et al. (2016), analyzing spiny palm species in areas with and without cattle in the Pantanal, concluded that the spines, mainly on the leaves, evolved as an adaptive response to herbivory and trampling of the past megafauna and continuous at present due to cattle and perhaps other wild animals that feed on these palm species. Additionally, the presence of spines in different parts of the palms can be a useful character to the taxonomy of Arecaceae (DRANSFIELD et al. 2008), including the genus Acrocomia, where higher densities of spines are observed on acaulescent species $A$. hassleri (Barb. Rodr.) W.J. Hahn and $A$. emensis (Toledo) Lorenzi and in the arboreal A. aculeata (Jacq.) Lodd. ex Mart., in contrast with the studied $A$. totai, that shows a lower density of spines on the leaves and the stipe, and the species $A$. corumbaensis Vianna S.A., A. crispa (Kunth) C.F. Baker ex Becc. and A. intumescens Drude that in the adult phase present smooth stipe and unarmed leaves (VIANNA; CAMPOS-ROCHA 2020; LORENZI et al. 2010).

The inflorescences of $A$. totai as well as of other species of the genus are light yellow when immature and dark yellow when mature, interfoliaceous, pedunculate, ramified at the first-order level, with pistillate flowers (female) immersed in alveolus in the basal third of the rachillas together with two staminated flowers (male) forming triads, and the staminated flowers distributed on the apical 2/3 of the rachillas, characteristic common to the members of the subfamily Arecoideae to which this species belongs (LORENZI et al. 2010; DRANSFIELD et al. 2008). The inflorescences are protected by a peduncular bract, woody, brown, normally tomentous, in the case of $A$. totai with dense velutine tomentum, which opens through a longitudinal split when the flowers are formed. We did not observe significant variation between inflorescences. In general, we observed only one open inflorescence per plant, being uncommon opening two or more inflorescences at a time. Under normal climatic conditions, most $A$. totai palms in the region flowered between September and January and ripe fruits start dropping in October, extending to December.

The analyzed infructescences or bunches showed a mean length of $71.07 \pm 9.87$ and a mean basal circumference of $82.07 \pm 11.99 \mathrm{~cm}$ (Table 1) smaller than those of A. aculeata and A. intumescens and larger size than the other species of the genus (VIANNA et al. 2017a; LORENZI et al. 2010), useful characters to identify the species. Each bunch contained a mean of $135.96 \pm 33.80$ rachillas and $392.30 \pm 134.53$ fruits. Bunches presented a mean of $1040 \pm 403.77$ floral scars per rachilla (Table 1).

Reproductive success is associated with the abortion rate and directly influences the potential fruit production (WIENS et al. 1987). The analyzed plants presented a mean abortion rate of $58.70 \%$, varying from $16.70 \%$ to $83.9 \%$, pointing out that some plants already had dropped some ripe fruits; thus, the mean actual abortion rate is lower than the calculated. According to Bawa and Webb (1984), abortion is a generalized phenomenon in plants and the group of palms; commonly less than $50 \%$ plants produce fruits that reach ripeness, due to high loss by abortion (STEVEN et al. 1987). That is caused by various factors, such as adverse climatic conditions, pollination deficiency, resource availability for fruit development by the mother-plant, abnormalities in the formation of ovules, endogamic depression, regulation of quality and quantity of seeds, predation, diseases and others (PEREIRA et al. 2014; WIENS et al. 1987; BAWA AND WEBB 1984; Stephenson 1981). Another fact related to abortion in palms is the long period of fruit development (DRANSFIELD et al. 2008; HENDERSON 2002), that implies in higher energy expenditure by the mother-plant and longer exposure time of the fruits to pathogens, insects or other predators, and climatic adversities.

The fruits presented longitudinal diameter (FLD) was larger than the equatorial diameter (DED), with a mean FLD/DED ratio of 1.28, giving them an elongated shape (Table. 1). The epicarp or peel in $82.22 \%$ of the evaluated plants was smooth, i. e., without trichomes (Figure $2 \mathrm{i}$ ), in $8.89 \%$ we observed stripes on the epicarp (Figure $2 \mathrm{~h}, 3 \mathrm{~b}$ ) and in most plants $(95.56 \%)$ a persistent calyx (Figure $2 \mathrm{j}, 3 \mathrm{c}$ ).

A particular characteristic of $A$. totai compared with the other species is the higher color variation of the epicarp and mesocarp, useful characters for both taxonomy and selection, being considered by extractivists in harvesting fruits according to the purpose. Fruits with yellow pulp are preferably used for the production of flour and the orange ones for ice cream (VIANNA 2011). We determined the epicarp colors visually as orangish, yellow, dark yellow, brown, yellowish-green and dark green; most plants had fruits with green peel $(28.89 \%)$ and few $(4.44 \%)$ orangish (Figure $2 \mathrm{k}, 3 \mathrm{e}$ ). The mesocarp or pulp was visually ranked into six colors: (i) yellow, (ii) orangish (iii) white, (iv) brown, (v) pinkish and (vi) red. Most fruits in the evaluated populations presented yellow pulp (33.33\%), followed by orangish pulp (22.22\%) (Figure 2 1, $3 \mathrm{~d}$ ). The red color was included because the extractivists named it so, but we would consider it as dark orange (Figure $3 \mathrm{~d}$ ). The green color of the epicarp does not indicate unripe fruits since we selected only plants with ripe fruits, as indicated by their abscission, mesocarp color and ease to remove the peel. 

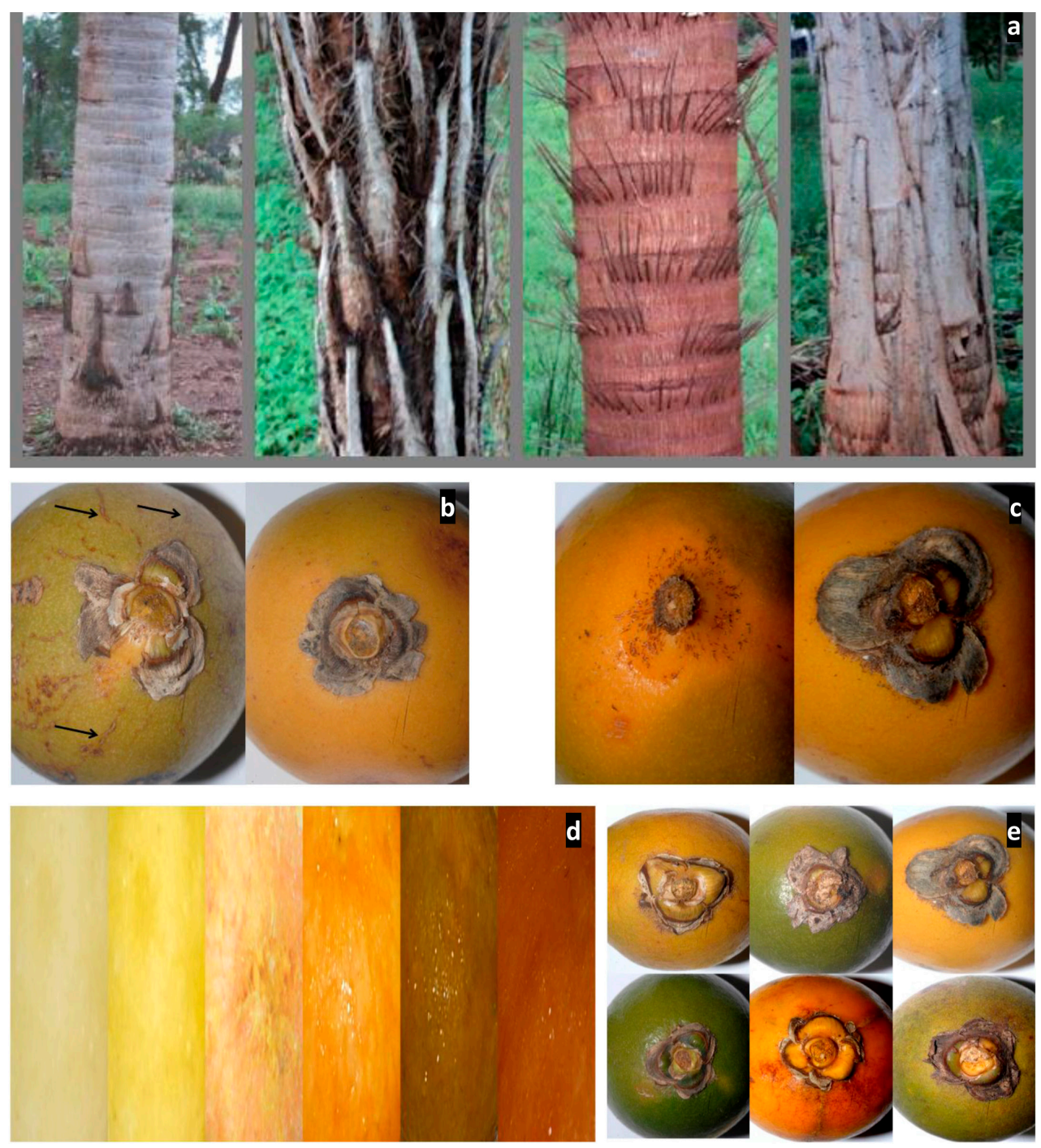

Figure 3. Variation of some morphological characters of Acrocomia totai of native populations in the western zone of the Pantanal in Mato Grosso do Sul: a presence or absence of leaf sheath remains and spines on the stipe, $\mathbf{b}$ presence or absence of stripes on the epicarp, $\mathbf{c}$ presence or absence of persistent calyx, $\mathbf{d}$ mesocarp colors, $\mathbf{e}$ epicarp colors.

The color variation observed in the epicarp and mesocarp of the analyzed A. totai plants probably results from the content and composition of carotenoids. According to Taiz et al. (2017), carotenoids are responsible for the color of ripe fruits, besides participating in the photosynthesis process and acting as photoprotective in plants. Although there is some research on carotenoids in species of Acrocomia (VALERIO et al., 2020; ARENA et al. 2018; SCHEX et al. 2018; OLIVEIRA et al. 2013; ROCHA et al. 2013; COIMBRA E JORGE 2011), none evaluated if fruits with different colors of peel and pulp showed distinct composition and quantities of carotenoids.

As pointed earlier, various morphological characters allow the distinction of $A$. totai from the other species of the genus. Besides morphological characteristics, reviewing reports from other fields, such as genetic diversity based on molecular markers, anatomy and centesimal composition of fruits, the separation of $A$. totai from the other species becomes evident. Lanes et al. (2015), applying microsatellite molecular markers in accesses of a germplasm bank with progenies from various localities of Brazil, found the formation of a well-structured genetic group, composed exclusively of A. totai plants from Pantanal in Mato Grosso do Sul, and separated from all other analyzed accesses. That strengthens the validity of $A$. totai as a species different from A. aculeata. Vianna et al. (2017 b), analyzing leaf anatomy data of the genus Acrocomia, corroborated the existence of seven species including the distinction of $A$. totai from the others. Research on nutritional composition and oil content in other Acrocomia species (LIEB et al. 2019; RÍO et al. 2016; ARAÚJO et al. 2014; SIERRAPÉREZ 2014; CONCEIÇÃO et al. 2012; BORA; ROCHA 2004) also show clear differences, not only useful to the taxonomy of the genus, as well as for better utilization of these resources. Acrocomia totai, with a lower mean oil content than A. aculeata, can be economically used for the production of functional foods, and secondly of oil with different applications, thus, enhancing and conserving this valuable native genetic resource. 


\section{Evaluation of agronomic interest characters}

We considered as 'agronomic characters' the data obtained through the evaluation of bunches, fruits and its parts, and pulp oil content to estimate the productivity of mass of peel, pulp, pyrene and pulp oil.

The mean yields of the various parts of all analyzed plants were that fruits presented $15.50 \pm 3.87$ of fresh mass $(\mathrm{g})$ and $8.94 \pm 2.42$ of dry mass $(\mathrm{g})$, with moisture loss around $42.32 \%$. The peel, pulp and pyrene had a mean fresh weight $(\mathrm{g})$ of $2.44 \pm 0.97,8.61 \pm 3.11$ and $4.96 \pm 1.00$, respectively, with mean dry mass $(\mathrm{g})$ of 1.56 $\pm 0.49,3.45 \pm 1.62,4.31 \pm 0.96$, respectively (Table 2). Regard to pulp oil (\%), the individuals of the analyzed populations presented a mean of $14.94 \pm 8.06 \%$ on a dry matter base (Table 2)

Table 2. Characterization of productivity data of Acrocomia totai of native populations located in the Pantanal, municipality of Corumbá, MS, Brazil.

\begin{tabular}{lcccc}
\hline Production characters & Minimum & Maximum & Mean \pm SD & CV\% \\
\hline Number of fruits per bunch & 138 & 805 & $392.30 \pm 134.53$ & 34.29 \\
Fresh mass of the whole fruit $(\mathrm{g})$ & 7.31 & 23.63 & $15.50 \pm 3.87$ & 24.95 \\
Fresh mass of the epicarp $(\mathrm{g})$ & 1.00 & 5.12 & $2.44 \pm 0.97$ & 39.93 \\
Fresh mass of the mesocarp $(\mathrm{g})$ & 1.09 & 18.21 & $8.61 \pm 3.11$ & 36.16 \\
Fresh mass of the pyrene $(\mathrm{g})$ & 2.65 & 7.48 & $4.96 \pm 1.00$ & 20.24 \\
Dry mass of the whole fruit $(\mathrm{g})$ & 4.10 & 17.41 & $8.94 \pm 2.42$ & 27.08 \\
Dry mass of the epicarp $(\mathrm{g})$ & 0.86 & 2.82 & $1.56 \pm 0.49$ & 31.46 \\
Dry mass of the mesocarp $(\mathrm{g})$ & 1.07 & 7.98 & $3.45 \pm 1.62$ & 46.97 \\
Dry mass of the pyrene $(\mathrm{g})$ & 1.86 & 7.11 & $4.31 \pm 0.96$ & 22.32 \\
Oil content of the mesocarp $(\%)$ & 1.19 & 34.70 & $14.94 \pm 8.06$ & 53.97 \\
Fresh mass of the bunch $(\mathrm{kg})$ & 757 & 6.19 & $3.32 \pm 1.48$ & 44.45 \\
Fruit yield per plant $(\mathrm{kg}) *$ & 8.86 & 53.00 & $30.15 \pm 11.68$ & 38.76 \\
Oil yield per plant ${ }^{-1}(\mathrm{~kg}) *$ & 0.02 & 3.88 & $0.96 \pm 0.83$ & 85.90 \\
\hline
\end{tabular}

* Considering 05 bunches per plant.

The contribution of each fruit part did not show much variation between analyzed plants. Based on fresh mass, the peel represents a mean of $14.00 \%$ of the fruit, the pulp $54.00 \%$ and the pyrene $32.00 \%$. Previously published data on the endocarp and the endosperm evaluated separately, their mean contribution was $23.30 \%$ and $6.70 \%$, respectively (CICONINI et al. 2013). However, the number of fruits, their fresh and dry mass, their parts and the oil content present high variation as can be seen in Table 2 and Figure 4. The fresh pulp mass per fruit in the evaluated natural populations, for example, is in mean $8.61 \mathrm{~g}$ with a variation coefficient of $36.16 \%$, weighing from $1.09 \mathrm{~g}$ to $18.21 \mathrm{~g}$. The oil yield is even more variable $(53.97 \%)$, with fruits with oil content as low as $1.19 \%$ up to $34.70 \%$.

The evaluation of the productivity of the studied plants of $A$. totai demonstrates that its utilization in extractive form is viable. The mean fresh mass yield of the whole fruit per plant is $30.15 \mathrm{~kg}$ and can be fractioned and used for various purposes. Approximately $17 \mathrm{~kg}$ of fresh pulp produced per plant can be transformed into the traditional flour or sold for ice cream and other food products. The endocarp, with a mean yield of $7.06 \mathrm{~kg}$ per plant, can serve as charcoal either as an energy source or to produce activated charcoal. The endosperm, with a yield of $2.06 \mathrm{~kg}$ per plant, can be destined to consumption in natura, processed into varied food products and extraction of its excellent quality oil, with application in pharmaceutical and cosmetic industries.

Though producing less than other oilseeds, planting A. totai at a density of 500 plants.ha $^{-1}$ can yield $480 \mathrm{~kg}$ oil. year-1 ${ }^{-1}$, superior to soybean (400 kg.ha.year ${ }^{-1}$ ), an annual crop demanding high investments, different from the palm, perennial and without much management cost and of natural occurrence in the region. As a hardy perennial, it is suitable for agroforestry. 

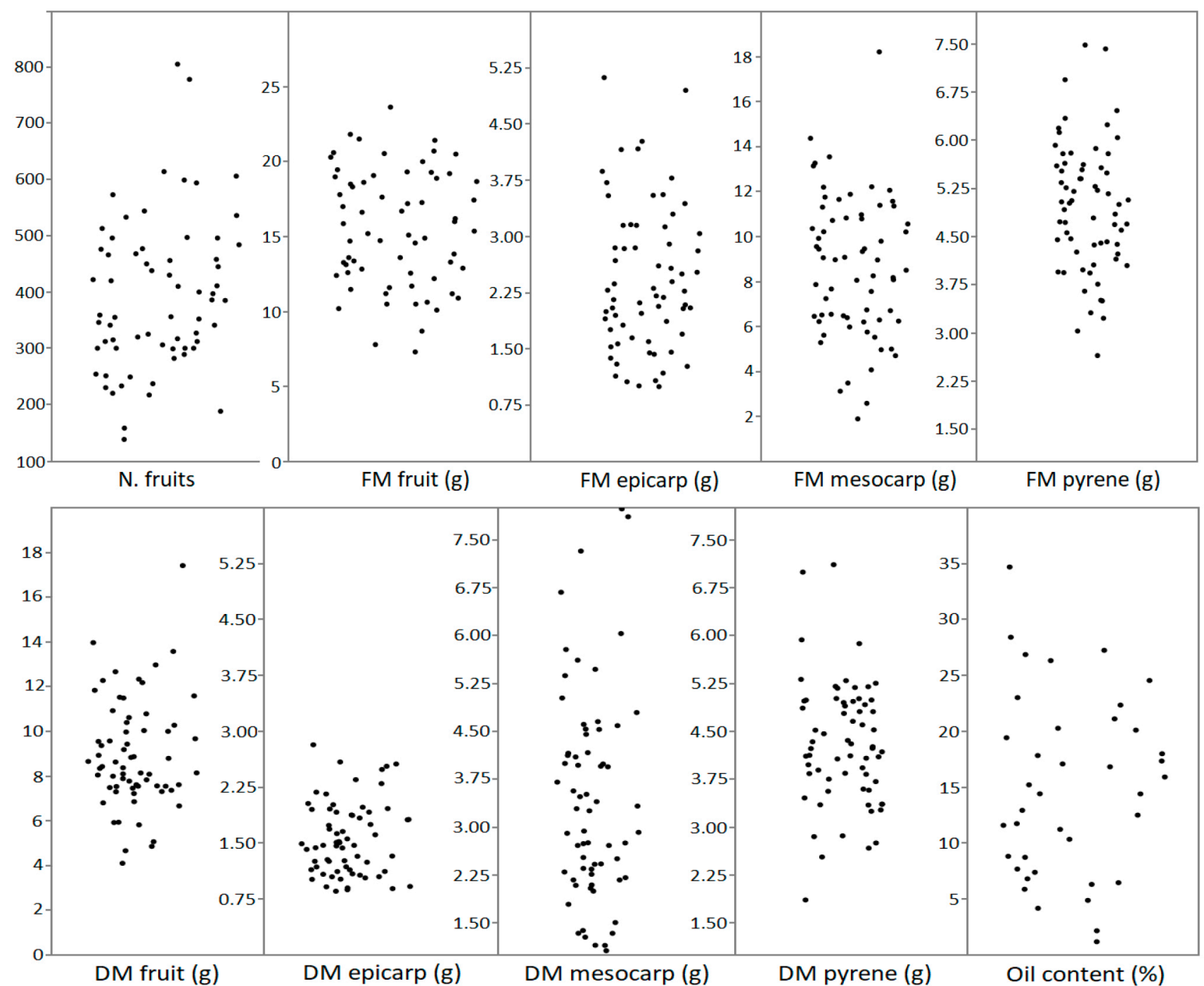

$\mathbf{N}$ number, FM fresh mass, $\mathbf{D M}$ dry mass

Figure 4. Distribution of production data of Acrocomia totai palms in natural populations in the Pantanal region.

The variation coefficients calculated for the analyzed productive characters are superior to $20.00 \%$ (Table 2, Figure 4). The dry mass and the pulp oil content, for example, presented variation coefficients of $46.97 \%$ and $53.97 \%$, respectively. That is excellent for selection aiming to improvement of the species since the genetic variability is fundamental for the success in the selection of desired characters or superior genotypes and their adjustment to environmental conditions (BRAMMER 2002). As observed in Figure 5, A. totai can have its productivity increased through the selection of the most productive individuals of the population, as demonstrated by simple selection of the most productive plants (third quartile), for example regarding the characters of pulp dry mass and oil content. With a density of 500 plants. $\mathrm{ha}^{-1}$, that would bring an increment of $57.90 \%$ in the yield of dry pulp mass that would increase from 8.31 t.ha $^{-1}$ in a cultivated population without any selection to 13.12 t.ha ${ }^{-1}$ with more productive selected plants, as well as oil content, that would double, from 0.48 t.ha ${ }^{-1}$ to 1.08 tha $^{-1}$, i. e., a rise of $55.60 \%$ in productivity. 

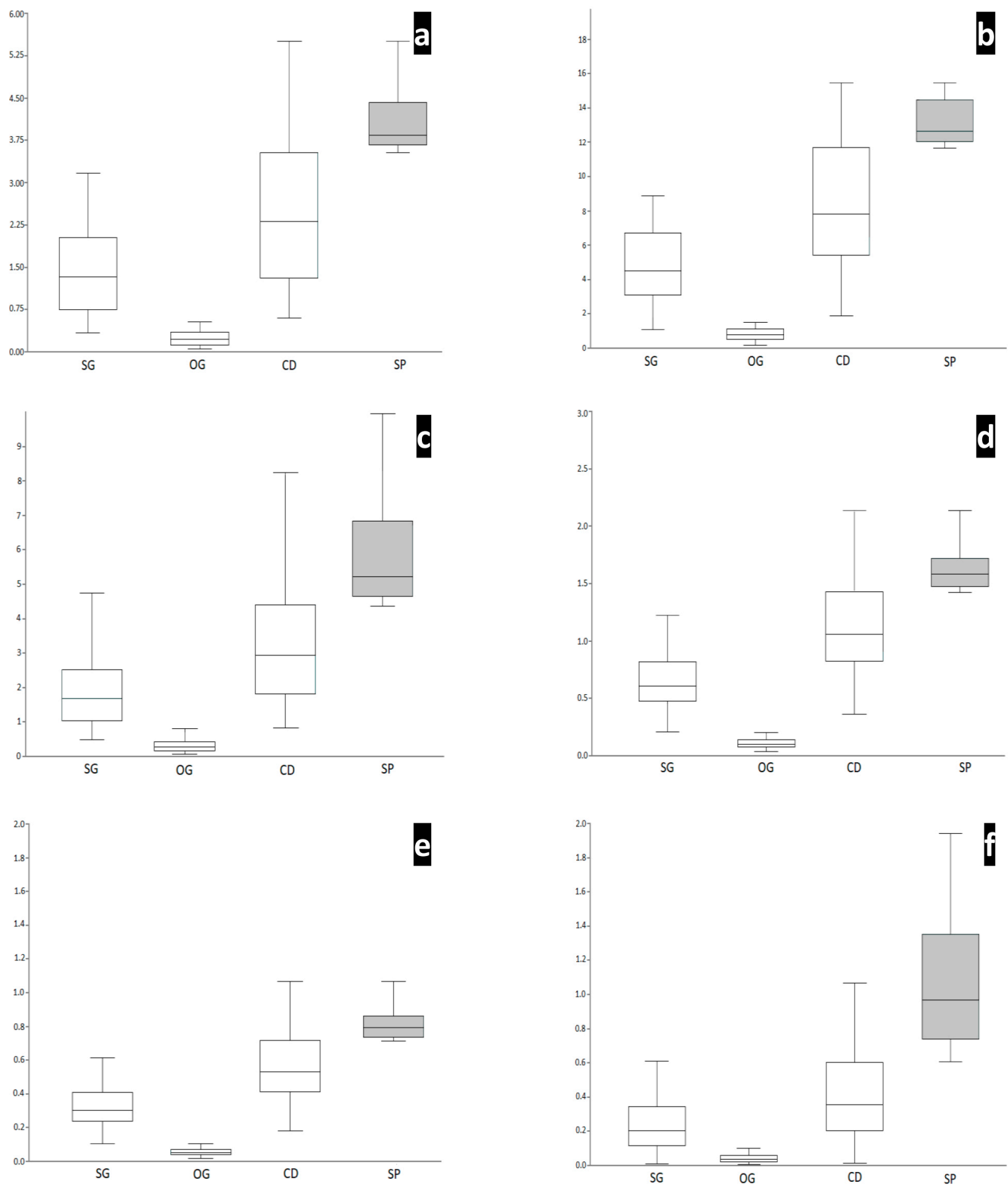

SG shrubby grassland, OG open grassland, CLT cultivated, SP selected plants

Figure 5. Estimates of productivity: a fresh mass of epicarp (g), b fresh mass of mesocarp (g), c dry mass of mesocarp $(\mathrm{g}), \mathbf{d}$ fresh mass of endocarp $(\mathrm{g}), \mathbf{e}$ fresh mass of endosperm, $\mathbf{f}$ oil content of mesocarp on a dry base (\%). 
Regard to genetic improvement, considering the two mentioned characters, it can be directed to the increase of oil productivity for several applications through the selection of plants with higher pulp oil contents or aimed to lower pulp oil content for the food industry. Another interesting character is pulp color, already considered by extractivists during harvest according to the desired final product. As shown by previous reports in the Pantanal region where populations of $A$. totai were analyzed (VIANNA 2011; VIANNA et al. 2015), the extractivists preferred orangish or red pulps to produce ice creams and yellow or pink pulp for flour. The genetic improvement allows selecting plants with the pulp colors of interest as well as to include other characters.

\section{Yield estimates in natural and cultivated populations}

Estimates of the populational density in natural areas of plant species of economic interest, production, yield of fruits and their component provide essential information for any economic activity, either extractivism or cultivation, also being relevant for planning actions of conservation of native species.

The estimates of populational density of the analyzed physiognomies extrapolated to an area of one hectare were 287 plants in 'open grassland' and 48 in 'shrubby grassland'. From the populational densities calculated for one hectare, we estimated the productive potential of fruits and each of their parts and the yield of pulp oil (Table 3).

Table 3. Production estimates of fruits (tons per hectare), their parts and oil in two physiognomies of the Pantanal and a hypothetic cultivated population considering 05 bunches per plant.

\begin{tabular}{lccc}
\hline Production character & Shrubby grassland & Open grassland & Cultivated \\
\hline FM whole fruit & $8.65 \pm 3.35$ & $1.45 \pm 0.56$ & $15.07 \pm 5.84$ \\
FM peel & $1.39 \pm 0.71$ & $0.23 \pm 0.12$ & $2.42 \pm 1.24$ \\
FM pulp & $4.77 \pm 2.12$ & $0.80 \pm 0.35$ & $8.31 \pm 3.69$ \\
FM pyrene & $0.33 \pm 0.06$ & $0.06 \pm 0.01$ & $0.58 \pm 0.12$ \\
FM nut & $0.10 \pm 0.02$ & $0.02 \pm 0.00$ & $0.17 \pm 0.03$ \\
DM pulp & $1.93 \pm 1.15$ & $0.32 \pm 0.19$ & $3.37 \pm 2.00$ \\
Pulp oil & $0.27 \pm 0.24$ & $0.05 \pm 0.04$ & $0.48 \pm 0.41$ \\
\hline
\end{tabular}

FM fresh mass, DM dry mass

It is critical to consider two factors for the sustainable exploitation of natural populations: (i) the variation of populational density and (ii) the variation of the desired productive characters, in our case, the production of fruits, their parts and pulp oil. The highest estimated productivities are evidently of the 'cultivated' population since all calculations of productivity were based on the number of plants per hectare (Table 3). However, it is necessary to consider that there are populations of $A$. totai with densities higher than those evaluated in our study, even higher than the indicated for cultivation (500 plants.ha-1). Indeed, one 'shrubby grassland' plot reached approximately 677 plants in a single hectare, with productivity worth to consider, moreover, harvesting through extractivism by local communities or in conservation areas where such activity could be made, reaching approximately 4.8 tons of fresh pulp and $270 \mathrm{~kg}$ of oil (Table 3, Figure $5 \mathrm{~b}, \mathrm{f}$ ).

Even in areas with lower populational densities, as occur in the evaluated 'open grassland', with 48 plants. $\mathrm{ha}^{-1}$, extractivism can be economically viable, inclusive for oil extraction, moreover increasing the populational density through planting, though without pre-determined spacing as in commercial crops. According to Oliveira et al. (2002), working on natural populations of "açaí palm" (Euterpe oleracea Mart.), in managed areas enriched by planting, the productivity of fruits was $9.000 \mathrm{~kg} \cdot \mathrm{ha}^{-1}$ compared with $4.500 \mathrm{~kg} \cdot \mathrm{ha}^{-1}$ in non-managed stands with reduced populational densities.

The box-plot graphs of Figure 5 named 'selected plants - SP' (grey box-plots) demonstrate how the simple selection of the most productive individuals within the detected variation can increase the yield characters. The example, the fresh mass yield of 8.31 th $^{-1}$ by a cultivated unselected population can increase to 13.12 t.ha $^{-1}$ just via a selection of the most productive plants, and oil from 0.48 t.ha ${ }^{-1}$ to 1.08 t.ha $^{-1}$. The selected individuals as 'superior' regard to production of the different analyzed characters correspond to those with values equal or superior to the third quartile. The real selection of individuals for improvement takes into consideration more morphological data and specific statistical analyses, however, this simple calculation using the third quartile here exemplifies the excellent potential for improvement of the species.

Although with distinct edaphoclimatic conditions, we assume that the yield differences between physiognomies are due to, in this case, primarily to the difference between population densities - areas with a higher number of plants produce more, if cultivated even more, and, if the most productive plants are selected, the increment will be even higher. More specific studies to determine the reason why the species occur in higher or lower population densities in distinct physiognomies 
would be highly interesting and can be carried out by researchers with such expertise.

\subsection{Considerations on conservation and cultivation of Acrocomia totai}

Besides the aspects considered before, we stress the social, economic and environmental importance of the utilization of native species. In the Pantanal, where our study was carried out, commercial crops such as soybean and corn are not viable because of floods. Thus, the prospection of native plant resources to be utilized either in an extractive way by traditional communities or cultivated is relevant, aiming to large scale production. Since the main activity in the Pantanal region is cattle ranching, there is the possibility of (i) systems integrating pastures, cattle and $A$. totai palm plantation, (ii) identification of natural palm thickets that can be exploited, (iii) cultivation of the palm in conservation areas, or (iv) enrichment of areas where the species once existed, aiming to increase of the offer of this resource for extractivism.

Populations of $A$. totai are also found native in other biomes and several vegetation types besides Pantanal, including Cerrado (VIANNA; CAMPOS-ROCHA 2020). In Cerrado, prevail commercial crops, being possible to have large scale sole cultivation of $A$. totai or its inclusion in different types of integration (crops-pasture-forest, pasture-forest, crops-forest) and agroforestry systems since palms allow intercropping with other species of various habits, including fruit trees, timber, forage species and annual crops (RODOLFO et al. 2020; MOREIRA et al. 2018). Additional to the exploitation of products and byproducts, the farmer growing the palm could have access to carbon credits (MOREIRA et al. 2020).

From the ecological point of view, it is necessary to consider the importance of maintaining the local biodiversity. Palms are ecologically important species for their role, such as food for the local fauna, including seasons of scarce resources, as they have a longer fruiting period than other plant species (PERES et al. 2000; GALETTI et al. 1992,1999). They associate with other plants, e. g., the orchid Vanilla palmarum (Salzm. ex Lindl.) Lindl., holoepiphyte to the A. totai palm (BARBAREMA et al. 2019). Nowadays, one of the threats to the conservation of natural populations of $A$. totai is the expansion of commercial plantations de $A$. aculeata in the region, selected for high pulp oil content, that in the long term can result in the disappearance of $A$. totai, as palms have a high possibility of interspecific and even intergeneric hybridization (FLOWERS et al. 2019; OTEYAMI et al. 2019; GUIMARÃES; SILVA 2012; BOVI et al. 1987).

Besides the environmental perspective, the conservation of native genetic resources is of high relevance for agriculture, especially for plant improvement since native populations present a broader genetic base, thus constituting sources of new genes that can be useful for enhancing resistance to diseases, pests and environmental adaptation (BRAMMER 2002; QUEIROZ et al. 1999; GUERRA et al. 1998). Socioeconomically, the preservation of natural populations of $A$. totai is fundamental for rural and traditional communities of the Pantanal region that rely on extractivism and processing of fruits as subsistence resource or income complement (AMARAL et al. 2019; VIANNA 2011). We point out that the way of exploitation by those communities assures a final product with better nutritional quality. Amaral et al. (2019) verified that although mechanized pulping optimizes production, compared with manual pulping, it does not keep all nutritional and functional characteristics of the essential oils and food fibers in A. totai pulp.

Last, we highlight the importance of correct botanical identification of the species. Reports in various scientific areas misidentified populations of $A$. totai as A. aculeata (e. g., CHUBA et al. 2019; LANES et al. 2015; MACHADO et al. 2015; CICONINI et al. 2013; SANJINEZ-ARGANDOÑA; CHUBA 2011), inclusively considering the supposed 'A. aculeata' of the Pantanal region as less productive for their smaller fruits and lower oil content, and so unsuitable for commercial cultivation. Thus, we recommend using reliable references about taxonomy and geographic distribution of the material to be studied, to understand differences and similarities and the economic potential of each species of Acrocomia, for better planning and implementing of commercial plantings, sustainable extractivism, obtention of products and byproducts, and guiding programs genetic breeding programs and conservation of native populations.

\section{Conclusions}

Acrocomia totai is morphologically different from the other species of the genus, presenting high variation within the evaluated populations regarding most analyzed characters, including those with commercial interest.

The analyses of the population densities and estimates of production demonstrate that $A$. totai can be explored, even satisfactorily under extractivism. Additionally, initiatives aiming the enrichment of the density of natural populations can raise productivity, increasing rentability.

The high variability detected in the analyzed production characters is of great importance for use in the genetic improvement of the species, base for the future selection of more productive genotypes according to the utilization target and management ease, allowing future launching of more productive and homogeneous genetic materials aiming large scale cultivation. 
We reinforce the need for the correct identification and characterization of native plant resources, such as the case of the studied species, that allows a better understanding of the found differences and similarities, their potential use and guide more efficiently research, conservation, cultivation, and commercial and industrial applications.

\section{Acknowledgments}

To Emanuelle Batista de Moura and Natália Dias Caldas Silva for helping with the collection and processing of the samples. To Professor Paulo Robson de Souza (Institute of Biosciences - UFMS) for the photos of the fruits. To Professor Priscila Aiko Hiane (Faculty of Pharmaceutical Sciences, Food and Nutrition - UFMS) for determining the oil content of the fruit samples used in the present work. To Felipe Rodrigues Inacio Oliveira for the treatment of the article's images.

\section{References}

AGUILERA, V.V.V; VIEDMA, S.E.; VEJA, C.N.; CAZZOLA, M.F.Y. Propriedades fisicoquímicas y de procesamiento de la pulpa de coco (Acrocomia aculeata) para su aplicación como ingrediente en un produto alimentício. Investigaciones Agrarias, Bogotá, v.20, n.1, p.51-57, 2018.

AMARAL, L.A.; LOUBET-FILHO, P.S.; CAVALHEIRO, L.F.; GALVANI, F.; SANTOS, E.F. Comparação das propriedades químicas e do perfil lipídico das farinhas de bocaiuva (Acrocomia spp.) despolpada de forma manual e mecânica. Revista de Agricultura Neotropical, Cassilândia, v.6, n.2, p.59-63, 2019.

ARAÚJO, B.C.P.; OLIVEIRA, D.A.; MELO-JÚNIOR, A.F.; BRANDÃO, M.M.; ROYO, V.A.; BATISTA, S.C.C.; MENEZES, E.V. Análise do óleo de Acrocomia emensis (Arecaceae) e potencial para produção de biodiesel. In: FÓRUM ENSINO-PESQUISA-EXTENSÃO: UNIVERSIDADE: SABERES E PRÁTICAS INOVADORAS, 8., 2014, Montes Claros. Anais [...]. Montes Claros: Universidade Estadual de Montes Claros, 2014.

ARENA, A.C.; JORGE, B.C.; SILVA, M.C.; BARROS, A.L.; FERNANDES, A.A.H.; NÓBREGA, R.H.; MARTINEZ, E.R.M.; CARDOSO, C.A.L.; ANSELMOFRANCHI, J.A.; MUZZI, R.M. Acrocomia aculeata oil: Beneficial effects on cyclophosphamide-induced reproductive toxicity in male rats. Andrologia, Berlin, v.50, n.6, p.e13028, 2018.
BARBAREMA, F.F.V.A.; SOUSA, T.S.; AMBROSIOMOREIRA, B.S.; ROQUE, N. What are the species of phorophytes of Vanilla palmarum (Orchidaceae) in Brazil? An assessment of emblematic specificity with palm tree species. Rodriguésia, Rio de Janeiro, v.70, e02732017, 2019.

BAWA, K.S.; WEBB, C.J. Flower, fruit and seed abortion in tropical forest trees: implications for the evolution of paternal and maternal reproductive patterns. American Journal of Botany, New York, v.71, n.5, p.736-751, 1984.

BORA, P.S.; ROCHA, R.V.M. Macaiba palm: fatty and amino acids composition of fruits. Ciência e Tecnologia de Alimentos, Campinas, v.4, n.3, p.158-162, 2004.

BOVI, M.L.A.; GODOY-JÚNIOR, G.; SÁES, L.A. Híbridos interespecíficos de palmiteiro (Euterpe oleraceax Euterpe edulis). Bragantia, Campinas, v.46, n.2, p.343363, 1987.

BRAMMER, S.P. Variabilidade e diversidade genética vegetal: requisito fundamental em um programa de melhoramento. Passo Fundo: Embrapa Trigo, 2002. 9 p.

BRASIL. Ministério da Saúde. Agência Nacional de Vigilância Sanitária (ANVISA). Métodos físico-químicos para análise de alimentos. Brasília, DF: Ministério da Saúde, 2005. 1018 p.

CARDOSO, E.L.; SPERA, S.T.; PELLEGRIN, L.A.; SPERA, M.R.N. Solos do Assentamento Urucumcaracterização, limitações e aptidão agrícola. Corumbá: Embrapa Pantanal, 2002. 35 p. ( Documentos, 30)

CARGNIN, A.; JUNQUEIRA, N.T.V.; FOGAÇA, C.M.; COSTA, C.J.; AGUIAR, J.L.P. Potencial da macaubeira como fonte de matéria prima para produção de biodiesel. In: SIMPÓSIO NACIONAL DO CERRADO, 9., SIMPÓSIO INTERNACIONAL DE SAVANAS TROPICAIS, 2., 2008. Brasília, DF. Anais [...]. 2008. Brasília, DF: ParlaMundi. 2008.

CHUBA, C.A.M.; SILVA, R.E.P.; SANTOS, A.C.; SANJINEZ-ARGADONAA, E.J. Development of a device to pulping fruits of bocaiúva (Acrocomia aculeata sp.): intended for the communities that practice sustainable agriculture or strativism. Journal of Agricultural Science, Cambridge, v.11, n.2, p.397-407, 2019. 
CICONINI, G.; FAVARO, S.P.; ROSCOE, R.; MIRANDA, C.H.B.; TAPETI, C.F.; MIYAHIRA, M.A.M.; BEARARI, L.; GALVANI, F.; BORSATO, A.V.; COLNAGO, L.A.; NAKA, M.H. Biometry and oil contents of Acrocomia aculeata fruits from the Cerrados and Pantanal biomes in Mato Grosso do Sul, Brazil. Industrial Crops and Products, Amsterdam, v.45, p.208-214, 2013.

COIMBRA, M.C.; JORGE, N. Proximate composition of guariroba (Syagrus oleracea), jerivá (Syagrus romanzoffiana) and macaúba (Acrocomia aculeata) palm fruits. Food Research International, v.44, p.2139-2142, 2011.

COLOMBO, C.A.; BERTON L.H.C.; DÍAZ, B.G.; FERRARI, R.A. Macaúba: a promising tropical palm for the production of vegetable oil. OCL- Oilseeds and fats, Crops and Lipids, Montrouge, v.25, n.1, D108, 2018.

CONCEIÇÃO, L.D.H.C.S.; JUNQUEIRA, N.T.V.; LICURGO, F.M.S.; ANTONIASSI, R.; WILHELM, A.E.; BRAGA, M.F. Teor de óleo em frutos de diferentes espécies de Macaubeira (Acrocomia spp.). In: CONGRESSO BRASILEIRO DE FRUTICULTURA, 22., 2012. Bento Gonçalves. Anais [...]. Bento Gonçalves: Sociedade Brasileira de Fruticultura, 2012. v.1., p. 4883-4886.

COSTA, A.M.; SPEHAR, C.R.; SERENO, J.R. Conservação de recursos genéticos no Brasil. Brasília: Embrapa, 2012. 672 p.

DAMASCENO-JÚNIOR, G.A.; SOUZA, P.R.; BORTOLOTTO, I.M.; RAMOS, M.I.L.; HIANE, P.A.; BRAGA-NETO, J.A.; ISHII, I.H.; COSTA, D.C.; RAMOS-FILHO, M.M.; GOMES, R.J.B.; BARBOSA, M.M.; RODRIGUES,R.B. Sabores do cerrado e do Pantanal - receitas e boas práticas de aproveitamento. Campo Grande: Editora UFMS, 2010. 141 p.

DRANSFIELD, J.; UHL, N.W.; ASMUSSEN, C.B.; BAKER, W.J.; HARLEY, M.M.; LEWIS, C.E. Genera Palmarum - the evolution and classification of palms. Kew: Royal Botanic Gardens, 2008. 732 p.

CLIMATE-DATA.ORG. Corumbá clima (Brasil): temperature, climate graph, climate table for Corumbá. 2020. Available at: https://pt.climate-data.org/america-dosul/brasil/mato-grosso-do-sul/corumba-31513

FLORES-JOHNSON, E.A.; CARRILLO, J.G.; ZHAI, C.; GAMBOA, R.A.; GAN, Y.; SHEN, L. Microstructure and mechanical properties of hard Acrocomia mexicana fruit shell. Scientific Reports, London, v.8, n.9668, 2018.
FLOWERS, J.M.; HAZZOURI, K.M.; GROSBALTHAZARD, M.; MO, Z.; KOUTROUMPA, K.; PERRAKIS, A.; FERRAND, S.; KHIERALLAH, H.S.M.; FULLER, D.Q.; ABERLENC, C.F.; PURUGGANAN, M.D. Cross-species hybridization and the origin of North African date palms. Proceedings of the National Academy of Sciences, Washington, v.116, n.5,p.1651-1658, 2019.

GALETTI, M.; PASCHOAL, M.; PEDRONI, F. Predation on Palm Nuts (Syagrus romanzoffiana) by Squirrels (Sciurus ingrami) in South-East Brazil. Journal of Tropical Ecology, Cambridge, v.8, n.1, p.121-123, 1992.

GALETTI, M.; ZIPARRO, V.B.; MORELLATO, P.C. Fruiting phenology and frugivory on the palm Euterpe edulis in a lowland Atlantic forest of Brazil. Ecotropica, Bogotá, v.5, p.115-122, 1999.

GÖLDEL, B.; ARAUJO, A.C., KISSING, W.D., SVENNING, J.C. Impacts of large herbivores on spinescence and abundance of palms in the Pantanal, Brazil. Botanical Journal of the Linnean Society, London, v.182, p.465-479, 2016.

GUERRA, M.P.; NODARI, R.O.; REIS, M.S.; ORTH, A.I. A diversidade dos recursos genéticos vegetais e a nova pesquisa agrícola. Ciência Rural, Santa Maria, v.28, n.3, p.521-528, 1998.

GUIMARÃES, C.A.L.; SILVA, L.A.M. Piaçava da Bahia (Attalea funifera Martius): do extrativismo à cultura agrícola. Ilhéus: Editus, 2012. 262 p.

HENDERSON, A. Evolution and ecology of Palms. New York: The New York Botanical Garden Press, 2002. $259 \mathrm{p}$.

HIANE, P.A.; RAMOS-FILHO, M.M.R.; RAMOS, M.I.L.; MACEDO, M.L.R. Óleo da polpa e amêndoa de bocaiúva, Acrocomia aculeata (Jacq.) Lodd. ex Mart. Caracterização e composição em ácido graxos. Brazilian Journal of Food Technology, Campinas, v.8, n.3, p.256-259, 2005.

KARIYAT, R.R.; HARDISON, S.B.; DE-MORAES, C.M.; MESCHER, M.C. Plant spines deter herbivory by restricting caterpillar movement. Biology Letters, London, v.13, n.20170176, 2017. 
LANES, E.C.M.; MOTOIKE, S.Y.; KUKI, C.N.; NICK, C.; FREITAS, R.D. Molecular characterization and population structure of the macaw palm, Acrocomia aculeata (Arecaceae), ex situ germplasm collection using microsatellites markers. Journal of Heredity, Washington, v.106, n.1, p.102-112, 2015.

LENTZ, D.L. Acrocomia mexicana: palm of the ancient Mesoamericas. Journal of Ethnobiology, Washington, v.10, n.2, p.183-194, 1990.

LIEB, V.M.; SCHEX, R.; ESQUIVEL, P.; JIMÉNEZ, V.M.; SCHMARR, H.G.; CARLE, R.; STEINGASS, C.B. Fatty acids and triacylglycerols in the mesocarp and kernel oils of maturing Costa Rican Acrocomia aculeata fruits. NFS Journal, München, v.14-15, p.6-13, 2019.

LORENZI, H.; KAHN, F.; NOBLICK, L.R.; FERREIRA, E. Flora Brasileira - Arecaceae (Palmeiras). Nova Odessa: Instituto Plantarum, 2010. 368 p.

MACHADO, W.; GUIMARÃES, M.F.; LIRA, F.F.; SANTOS, J.V.F.; TAKAHASHI, L.S.A.; LEAL, A.C.; COELHO, G.T.C.P. Evaluation of two fruit ecotypes (totai and sclerocarpa) of macaúba (Acrocomia aculeata). Industrial Crops and Products, Amsterdam, v.63, p.287-293, 2015.

MARCONDES, L.; DUTRA, Z.M.; SARAIVA, E.F.; VIGAS, V.P.; BRITES, B.F. Aceitação sensorial de bala funcional de bocaiuva (Acrocomia spp.). Cadernos de Agroecologia, Rio de Janeiro, v.13, n.2, p.1-8, 2018.

MORAES, R.M. Flora de palmeras da Bolívia. La Paz: Plural Editores, 2004. 484 p.

MORCOTE-RÍOS, G.; BERNAL, R. Remains of palms (Palmae) at archaeological sites in the new world: a review. The Botanical Review, Dordrecht, v.67, n.3, p.309-350, 2001.

MOREIRA, L.S.; PIRES, C.V.; MARCATTI, G.E.; SANTOS, R.H.S.; IMBUZEIRO, H.M.A.; FERNANDES R.B.A. Intercropping of coffee with the palm tree, macauba, can mitigate climate change effects. Agricultural and Forest Meteorology, Amsterdam, v.256-257, p.379-390, 2018.

MOREIRA, S.L.S.; IMBUZEIRO, H.M.A.; SILVERT, C.; DIETRICH, O.H.; PIMENTEL, L.D.; FERNANDES, R.B. Above- and below-ground carbon accumulation in cultivated macauba palm and potential to generate carbon credits. Journal of Cleaner Production, Amsterdam, v.265, n.121628, 2020.
MUNHOZ, C.L.; GUIMARÃES, R.C.A.; NOZAKI, V.T.; SANJINEZ-ARGADOÑA, E.J.; MACEDO, M.L. Composição química e de fatores antinutricionais de frutos de bocaiuva. Ambiência, Guarapuava, v.14, n.1, p.: 212-224, 2018a.

MUNHOZ, C.L.; GUIMARÃES, R.C.A.; SANJINEZARGADOÑA, E.J.; MALDONADE, I.R. Lipid nutritional quality of the pulp and kernel of bocaiuva (Acrocomia aculeata (Jacq.) Lodd). Ambiência, Guarapuava, v.14, n.2, p.343-335, 2018b.

OLIVEIRA, D.M.; COSTA, J.P.; CLEMENTE, E.; COSTA, J.M.C. Characterization of grugru palm pulp for food applications. Journal of Food Science and Engineering, Libertyville, v.3, p.107-112, 2013.

OLIVEIRA, J.E. Guató: argonautas do Pantanal.Porto Alegre: EDIPUCRS, 1996. 179 p. (Coleção Arqueologia, 2)

OLIVEIRA, M.S; CARVALHO, J.E.U.; NASCIMENTO, W.M.O.; MÜLLER, C.H. Cultivo do açaizeiro para produção de frutos. Belém: Embrapa Amazônia Oriental, 2002. 18 p. (Circular Técnica, 26)

OTEYAMI, M.; ZANNOU, E.T.; COFFI, A. Evaluation of palm trees hybrids (inter specific backcross BC1) $E$. oleifera $\times E$. guineensis for their sensitivity to the attacks of the leaf miner. Advances in Agriculture and Environmental Science, Budapest, v.2, n.1, p.1-6, 2019.

PATIÑO-RODRIGUEZ, V.M. Historia y dispersion de los frutales nativos del neotrópico. Cali: Centro Internacional de Agricultura Tropical - CIAT, 2002. 655 p.

PEREIRA, A.C.F.; FONSECA, F.S.A.; MOTA, G.R.; FERNANDES, A.K.C.; FAGUNDES, M.; REISJÚNIOR, R.; FARIA, M.L. Ecological interactions shape the dynamics of seed predation in Acrocomia aculeata (Arecaceae). PLoS ONE, v.9, n.5, e98026, 2014.

PERES, C.A. Identifying keystone plant resources in tropical forests: the case of gums from Parkia pods. Journal of Tropical Ecology, Cambridge, v.16, p.287$317,2000$.

POTT, A.; POTT, V.J. Plantas do Pantanal. Brasília, DF: Embrapa, 1994. 320 p. 
POTT, E.B. Teores de minerais e proteína bruta em plantas forrageiras da parte alta de Corumbá, MS. Corumbá: Embrapa - Centro de Pesquisa Agropecuária do Pantanal, 1986. 6 p. (Comunicado Técnico, 6).

QUEIROZ, M.A.; GOEDERT, C.O.; RAMOS, S.R.R. Recursos genéticos e melhoramento de plantas para o Nordeste Brasileiro. Petrolina: Embrapa Semi-árido / Brasília: Embrapa Recursos Genéticos Vegetais, 1999. 1066 p.

RAMOS, M.I.L.; RAMOS-FILHO, M.M.; HIANE, P.A.; BRAGA-NETO, J.A.; SIQUEIRA, E.M.A. Qualidade nutricional da polpa de bocaiúva Acrocomia aculeata (Jacq.) Lodd. Ciência e Tecnologia de Alimentos, Campinas, v.28, p. 90-94, 2008. Suplemento

RÍO, J.C.; EVARISTO, A.B.; MARQUES, G.; MARTÍNRAMOS, P.; MARTÍN-GIL, J.; GUTIÉRREZ, A. Chemical composition and thermal behavior of the pulp and kernel oils from macauba palm (Acrocomia aculeata) fruit. Industrial Crops and Products, Amsterdam, v.84, p. 294-304, 2016.

ROCHA, M.S.; FIGUEIREDO, R.W.; ARAÚJO, M.A.M.; MOREIRA-ARAÚJO, R.S.R. Caracterização físicoquímica e atividade antioxidante (in vitro) de frutos do cerrado piauiense. Revista Brasileira de Fruticultura, Jaboticabal, v.35, n.4, p.4933-941, 2013.

RODOLFO, G.H.M.; ROA, J.P.B.; LEONEL, M.S.; COSTA, A.S.V.; NELSON, D.L.; RODOLFO, L.B. estudo do impacto da adoção de sistemas agroflorestais com palmeira macaúba (A. aculeata) em áreas de reserva legal no Vale do Jequitinhonha-MG. Brazilian Journal of Development, Curitiba, v.6, n.3, p.14938-14950, 2020 .

SANJINEZ-ARGANDOÑA, E.J.; CHUBA, C.A.M. Caracterização biométrica, física e química de frutos da palmeira bocaiúva Acrocomia aculeata (Jacq) Lodd. Revista Brasileira de Fruticultura, Jaboticabal, v.33, n.3, p.1023-1028, 2011.

SCHEX, R.; LIEB, VM; JÍMENEZ, V.M.; ESQUIVEL, P.; SCHWEIGGERT, R.M.; CARLE, R.; STEINGASS, C.B. HPLC-DAD-APCI/ESI-MSn analysis of carotenoids and $\alpha$-tocopherol in Costa Rican Acrocomia aculeata fruits of varying maturity stages. Food Research International, New York, v.105, p.645-653, 2018.
SIERRA-PÉREZ, R.C.; GONZÁLEZ-CANAVACIOLO, V.L.; RODRÍGUEZ-LEYES,A.; MARRERO-DELANGE, D.; VICENTE-MURILLO, R.; MORALES-RICO, C.L. Estudio fitoquímico de los frutos de Acrocomia crispa, palma endémica cubana. Revista CENIC Ciencias Químicas, Habana, v.45, p.41-47, 2014.

SILVA, V.M.; CAMPOS, R.P.; BORSATO, A.V.; CANDIDO, C.J.; DONADON, J.R. Bocaiuva jelly: preparation, physicochemical and sensory evaluation. Revista Brasileira de Fruticultura, Jaboticabal, v.40, n.5, e-846, 2018.

SILVA, G.C.; HADDAD, F.F.; MAGALHÃES, K.T.; NUNES, C.A. Óleo de amêndoa de macaúba tem potencial como ingrediente lipídico em margarina e maionese. Revista Agrarian, Dourados, v.13, n.47, p.22-129, 2020.

SOUZA, G.K.; SCHUQUEL, I.T.A.; MOURA, V.M.; BELOTTO, A.C.; CHIAVELLI, L.U.R.; RUIZ, A.L.T.; SHIOZAWA, L.; CARVALHO, J.E.; GARCIA, F.P.; KAPLUM, V.; RODRIGUES, J.H.S.; SCARIOT, D.B.; DELVECHHIO, R.; MACHADO-FERREIRA, E.; SANTANA, R.; SOARES, C.A.G.; NAKAMURA, C.V.; SANTIN, S.M.O.; POMINI, A.M. X-ray structure of O-methyl-acrocol and anti-cancer, anti-parasitic, antibacterial and anti-Zika virus evaluations of the Brazilian palm tree Acrocomia totai. Industrial Crops \& Products, Amsterdam, v.109, p.483-492, 2017.

STEPHENSON, A.G. Flower and fruit abortion: proximate causes and ultimate functions. Annual Review of Ecology and Systematics, Palo Alto, v.12, p.253-279, 1981.

STEVEN, D.D. Vegetative and reproductive phenologies of a palm assemblage in Panama. Biotropica, Lawrence, v.19, p.342-356, 1987.

TAIZ, L.; ZEIGER, E.; MOLLER, IM. MURPHY, A. Fisiologia e desenvolvimento vegetal. 6.ed. Porto Alegre: Artmed, 2017. 858 p.

THE PLANT LIST. A working list of all plant species. Version 1.1. 2013. Available at : http://www.theplantlist. $\underline{\text { org }}$

TROPICOS. Connecting the world to botanical data since 1982. Missouri Botanical Garden, 2021. Available at: http://www.tropicos.org 
VALERIO, P.P.; FRIAS, J.M.; CREN, E.C. Thermal degradation kinetics of carotenoids: Acrocomia aculeata oil in the context of nutraceutical food and bioprocess technology. Journal of Thermal Analysis and Calorimetry, Dordrecht, 2020. Disponível em: https:// doi.org/10.1007/s10973-020-09303-9

VIANNA, S.A. Caracterização da variabilidade fenotípica de Acrocomia aculeata (Jacq.) Lodd. ex Mart. (Arecaceae): etnobotânica, morfologia, produtividade e composição nutricional. 2011. Dissertação (Mestrado em Biologia Vegetal) - Universidade Federal de Mato Grosso do Sul, Campo Grande, 2011.

VIANNA, S.A.; HIANE, P.A.; JORDÃO, M.N.; COSTA, E.C.; POTT, A. Physical and nutritional assessment of fruits of Acrocomia aculeata (Jacq.) Lodd. ex Mart. (Arecaceae) based on pulp color. Revista Biodiversidad Neotropical, Quibdó, v.5, n.2, p.89-95, 2015.

VIANNA, S.A.; BERTON, L.H.C.; POTT, A.; CARMELLO-GUERREIRO, S.M.; COLOMBO, C.A. Biometric characterization of fruits and morphoanatomy of the mesocarp of Acrocomia species (Arecaceae). International Journal of Biology, Kingston, v.9, n.3, p.78-92, 2017a.
VIANNA, S.A.; CARMELLO-GUERREIRO, S.M.; NOBLICK, L.R.; COLOMBO, C.A. Leaf anatomy of Acrocomia (Arecaceae): an additional contribution to the taxonomic resolution of a genus with great economic potential. Plant Systematics and Evolution, Wien, v.303, n.2, p.233-248, 2017b.

VIANNA, S.A.; CAMPOS-ROCHA, A. Acrocomia in Flora do Brasil 2020 em construção. Rio de Janeiro: Jardim Botânico, 2020. Available at: http://floradobrasil. jbrj.gov.br/reflora/floradobrasil/FB15662.

WARREN, J. The nature of crops: How we came to eat the plants we do. Oxfordshire, CABI, 2015. 191 p.

WIENS, D.; CALVIN, C.L.; WILSON, C.A.; DAVERN, C.I.; FRANK, D.; SEAVEY, S.R. Reproductive success, spontaneous embryo abortion and genetic load in flowering plants. Oecologia, Berlin, v.71:501-509, 1987.

WILLIS, K.J. State of the world's plants 2017. Kew: Report. Royal Botanic Gardens, 2017. 96 p. 